\title{
Electoral systems and income inequality: a tale of political equality
}

\author{
Izaskun Zuazu' ${ }^{1}$
}

Received: 11 October 2020 / Accepted: 30 September 2021 / Published online: 21 October 2021

(c) The Author(s) 2021

\begin{abstract}
The link between democracy and within-country income inequality remains an unresolved quest in the literature of political economy. To look into this debate, I propose exploring the implications of electoral systems, rather than political regimes, on income inequality. I surmise that proportional representation systems should be associated with lower income inequality than majoritarian or mixed systems. Further, I conjecture that the relationship between electoral systems and income inequality hinges on the de facto distribution of real political power, namely political equality. I use data on 85 countries covering the period 1960-2016 and specify models able to capture the persistence and mean reversion of income inequality. The estimates fail to significantly associate democracy with income inequality, and find other political institutions to significantly shape income inequality. The paper finds a robust association between more proportional systems and lower income inequality. However, this association depends on political equality. Changes towards proportional representation systems seem to lower income inequality at low and medium levels of political equality. Strikingly, instrumental variable estimates show that changes in electoral systems in political equal societies increases income inequality.
\end{abstract}

Keywords Political equality · Income inequality · Proportional representation systems $\cdot$ Panel data

JEL classifications D63 $\cdot$ D72 $\cdot$ C23

\section{Introduction}

Economic inequality has experienced a remarkable increase since the 1970 s in virtually all Western democracies (Piketty 2014; Atkinson 2015). Along with the current rise of

Izaskun Zuazu

izzuazu@gmail.com; izaskun.zuazu-bermejo@uni-due.de

1 Institute for Socio-Economics, University of Duisburg-Essen, Duisburg, Germany 
wealth inequality, a challenging feature emerges from the data on income inequality. Today's pattern of economic inequality is largely shaped by an increasingly polarised distribution of incomes and the persistence of intergenerational inequalities. Income inequality of such a nature has crucial socio-economic implications, ranging from reducing economic sustainability to unleashing more rigid social hierarchies, and establishing features typical of a feudal society (Franzini and Pianta 2015). These rising trends of income inequality in democracies are at odds with the predictions of the commonly used model in existing political economy literature, the so-called medianvoter model (Meltzer and Richard 1981). That model argues that democratisation should lead to the implementation of pro-poor policies and ultimately reduce inequality. However, what we see in real world economics is quite the opposite. Why do we see rising levels of income inequality in established democracies then? Empirical literature on the link between democracy and income inequality is still full of contradictory results (Acemoglu et al. 2015). Democracy is indeed associated with either increasing or decreasing income inequality, findings that vary depending on country and time coverage in the datasets, estimation techniques or measures of democracy (Krauss 2016). Along these lines, recent literature suggests that democracy in itself might not warrant institutional or economic improvements (Chong and Gradstein 2019; Wong 2021; Bahamonde and Trasberg 2021). Hence, analysing the inequality effect of other institutional changes beyond democracy seems worth considering.

The current paper empirically tests two main hypotheses. Firstly, it distinguishes countries on the basis of other de jure political features such as electoral systemsrather than political regimes (i.e. democracy) — to shed some light on the existing conflicting results in democracy-inequality literature. Electoral systems are formal institutions that translate votes into seats in parliaments on the basis of different rules and result in varying degrees of political representation of societal groups. There is an array of potential channels, as further discussed in the paper, that might induce alternative distributive effects of electoral systems. Hence, the paper first tests whether electoral systems translate into different levels of within-country income inequality. Secondly, the paper hypothesises that the inequality impact of electoral systems depends on de facto distribution of real political power, namely political equality.

Democracy and political equality are highly related but distinct concepts. The differentiation boils down to the formal or de jure essence of the conceptualisation of democracy as a political regime, and the informal or de facto nature of political equality, which is borne out in actual human interaction (Voigt 2013). Hence, political equality refers to the extent to which real political power is evenly distributed across socio-economic groups by means of similar participation in civil society organisations, voter turnout, and ability to implement and monitor the political agenda.

The way in which democracy is defined and measured focuses on the characterisation of political regimes, rather than how citizens exercise their political will. ${ }^{1}$ Indeed,

\footnotetext{
1 Consider for instance the definition in Boix et al. (2013), a well-known and extensively used measure of democracy. A country is considered democratic if it satisfies conditions for both contestation (i) 'The executive is directly or indirectly elected in popular elections and is responsible either directly to voters or to a legislature'; (ii) 'the legislature (or the executive if elected directly) is chosen in free and fair elections', and participation (iii) 'a majority of adult men has the right to vote.' In this definition, women are excluded in the consideration of what a democracy is.
} 
although democracies hold higher levels of political equality than non-democracies, there is substantial variation in levels of political equality within democratic regimes (Houle 2018). The demand for data on political equality dates back to Verba and Orren (1985), and the present paper benefits from the availability nowadays of quantitative methods and data coverage (Bartels 2017; Pemstein et al. 2015; Houle 2018). Disentangling the effects of de jure and de facto conceptualisations of democratic politics might ultimately provide a better insight into the link between democracy and inequality, as extant literature has done regarding the link between political institutions and economic growth (Spruk 2016; Hartmann and Spruk 2020).

Using a database with information on 85 countries covering the period 1960-2016, I tested whether electoral systems and their interplay with political equality are associated with within-country income inequality. I specified static and dynamic panel data models and used annual and non-overlapping 5-year and 10-year periods that include a variety of empirically-informed drivers of income inequality. The results can be summarised as follows:

(i) Estimates point to more proportional parliaments as potential deterrents of income inequality.

(ii) This relationship depends inversely on the level of political equality. The interaction between electoral systems and political equality is found to be significant, by which electoral systems reduce income inequality at low or median levels of political equality. In highly political equal societies, changes towards more proportional electoral systems can rise income inequality.

(iii) Estimates do not significantly associate democracy with income inequality, although it seems that the age of a democracy might play a marginal role.

The remainder of the text is structured as follows. Section 2 reviews the literature and provides the main theoretical arguments of the hypothesis. Section 3 explains the data, the econometric models, and main results. Section 4 concludes.

\section{Democracy and income inequality: an on-going puzzle}

At first glance, democratic regimes might be expected to be more likely to implement inequality-correcting policies and should thus be associated with lower levels of income inequality. ${ }^{2}$ Against this posit, current trends show that democratic governments coexist quite callously with rising levels of income inequality. Yet empirical economics literature on democracy and inequality seems far from reaching a consensus, as they associates democracy with either a negligible or increasing effect on income inequality (Dreher and Gaston 2008; Scheve and Stasavage 2009; Acemoglu et al. 2015).

Figure 1 employs data on the sample of countries used in the econometric analysis below to plot the correlation between pre-tax income inequality ( $y$-axis), measured with the pre-tax Gini index collected from the Standardized World Income Inequality

\footnotetext{
2 Theoretical and empirical challenges of the workhorse model of democracy-inequality literature (Meltzer and Richard 1981) are for instances Benabou (2000) and Milanovic (2000). See Midtbø (2018) for a recent test using individual data and Bayesian methods.
} 
Fig. 1 Correlation between democracy and income inequality, by population size

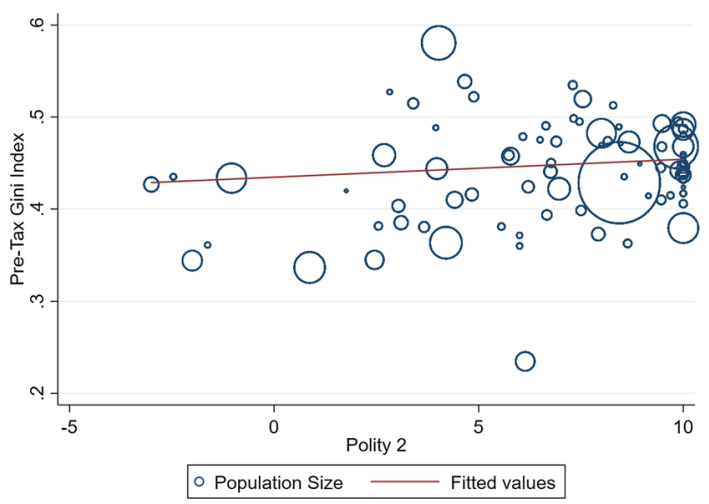

Democracies

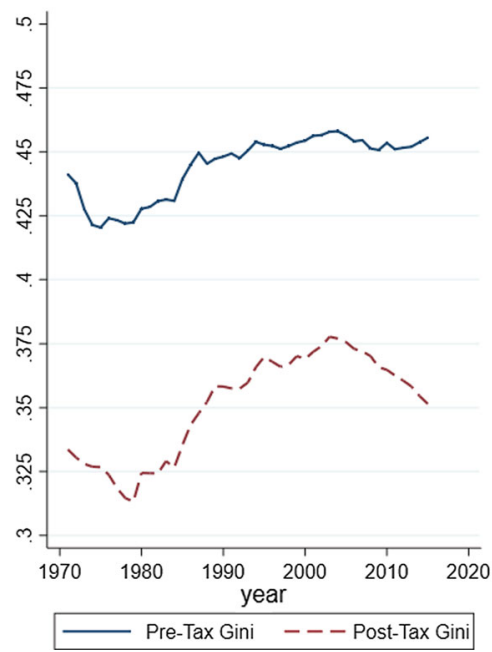

Non-Democracies

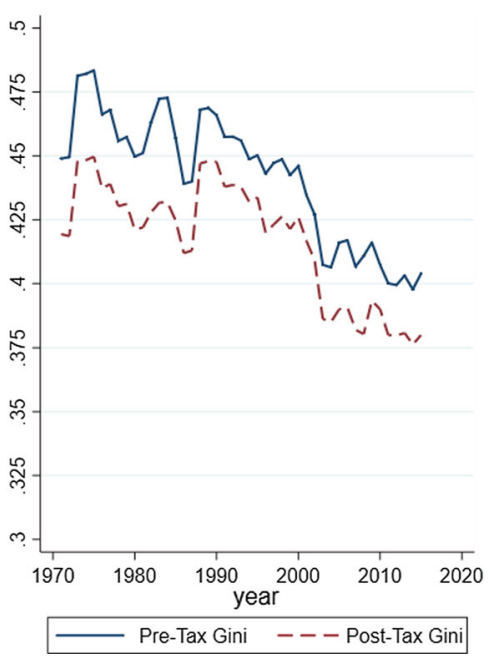

Fig. 2 Evolution of pre-tax and post-tax gini indices in democracies and non-democracies

Database (SWIID), and democracy ( $x$-axis), measured with the Polity2 index of the Polity IV Project (Marshall et al. 2017). Although Gini indices satisfy the criteria for comparing income distributions across countries and over time irrespectively of their population size or their aggregate income (Cowell 2000), it is interesting to consider a human welfare perspective of income distribution across countries (Sala-i Martin 2006). To visually account for that, the size of the dots in Fig. 1 is proportional to the sample countries' population size, where the biggest dot corresponds to India. The correlation between democracy and income inequality seems to be weak and slightly positive.

Figure 2 shows the evolution of both pre-tax and post-tax Gini indices in democratic and non-democratic countries in the sample. Democracies show on average an increasing trend in income inequality and a reduction of redistribution during the whole period considered (1970-2016), although there is a reducing post-tax income inequal- 
ity trend in the turn of the 20th century. Non-democracies show reducing levels of income inequality, both in terms of pre-market and post-market inequality. Among the reasons behind rising pre-tax and post-tax income inequality in democracies, the literature highlights firstly, that voters' political preferences go beyond income distribution issues (Roemer 2009), secondly, that powerful elites might capture democratic institutions to distort the implementation of pro-poor policies (Larcinese 2011; Berlinski et al. 2011; Acemoglu et al. 2013), thirdly, that democracy unleashes inequality-enhancing structural changes (Bergh 2005; Acemoglu et al. 2015), and fourthly, a biased middle class that does not pursue equalising policies (Aidt et al. 2010; Besley et al. 2010; Acemoglu et al. 2015). In either of these four propositions, the link between democracy and inequality ambiguously depends on specific features, such as the interplay between de jure and de facto political power distribution, the structural transformation of the economy and the distance between the median and mean voter's preferences of the level of redistribution and types of public policies.

\subsection{Proportionality of parliaments and income inequality}

This paper studies whether and how electoral systems affect income inequality. Electoral systems crucially channel voters' preferences to the policies implemented by the government, and are divided into proportional representation (PR, henceforth) systems (used in countries like Israel or Spain), majoritarian systems (United States, United Kingdom, France or Canada) and mixed systems (Germany, New Zealand or Hungary). ${ }^{3}$

Constitutional political economy literature provides stylised facts about how the choice of electoral system affects the economy at large, and income inequality and redistribution in particular. Electoral systems are primary able to encourage or discourage strategic voting behaviour (Boix 1999), where majoritarian systems enforce voter coordination and second-ranked political platforms. To the contrary, PR systems provide less incentives to vote strategically because seats in parliaments under that rules can be gained with only a fraction of the total vote, and thus, allowing voters to pursue their preferred political platforms. Majoritarian rules conduce to unstable policy choices Cox and McCubbins (1994), whereas PR systems, characterized by higher propensity of form coalitions in governments, provide higher levels of institutional stability. More consensual and stable policy-making can favour the reduction of income inequality. Other channels in which electoral systems can unleash distributional effects are through geographic concentration and the magnitude of districts (Rickard 2012) and the strength of lobbying activities (Naoi and Krauss 2009). Electoral systems can also influence income inequality levels on the basis of international trade-oriented (Kono 2009), the political representation of minorities (Norris et al. 2004), and the political ideology of governments (Iversen and Soskice 2006).

This body of research speaks to the sensitivity of governments to cater to different groups in the electorate, which may in turn lead to different levels of income inequality. Overall, the evidence tends to show that PR systems have greater redistribution and

\footnotetext{
3 See Herron et al. (2018) and Bormann and Golder (2013) for a characterisation and explanation of electoral systems.
} 
public spending than majoritarian systems (Persson and Tabellini 2004; Lizzeri and Persico 2001). Along these lines, this paper argues that the relative greater social spending and public policies associated with more proportionality in parliaments may unleash further distributional effects. Alternative electoral systems are associated with different social provisioning of education, health and inequality-correcting policies that levelling up the demand-side factors of the labor market Persson et al. (2007), Lizzeri and Persico (2001), and therefore, pre-market income inequality can be reduced or increased under alternative systems.

The current paper makes a crucial distinction between the effects of electoral systems in income inequality and redistribution. PR systems are usually associated with both higher public spending, which can be related more easily with political platforms aiming at reducing pre-tax income inequality, and redistribution, that ca be more attributable to post-tax income inequality. It should be noted that the choice of electoral systems are also influenced by economic and income inequality factors. A change of the electoral system can occur as a threat of opposition from the electorate (Boix 1999; Chang and Higashijima 2021), implying a two-way causal link between the choice of electoral systems and levels of income inequality and redistribution. ${ }^{4}$ Generally, pre-tax income inequality can be less visible to the electorate, implying a weaker link between income inequality and change of electoral systems than in the case of post-tax income inequality.

Based on these stylized facts of previous works in the reference literature, the key argument in the current paper is that changes towards more proportional parliaments should be associated with lower income inequality. Higher proportionality in parliaments reflects a higher consistency between votes and seats, which allow demands for inequality-reducing policies and general interest public spending programs (e.g. education, health, social security) to gain political representation. This might ultimately lead to reducing income inequality. Pre-tax income distribution might be crucially influenced by the welfare state in general, and by the electoral system, in particular. The intergenerational distribution of income, the labour supply and the feedback behavioural effects of tax and transfers in the workforce, and through levelling the playing field of public policies such as education (Bergh 2005), are among the channels through which electoral systems can affect pre-tax income inequality.

The right plot in Fig. 3 gives a hint of the different pre-tax and post-tax income inequality levels in PR systems and non-PR systems (majoritarian systems and mixed systems) during the period under scrutiny. The sample countries under proportional rules show on average higher levels of pre-tax Gini index, although there is a convergence between PR and non-PR countries in recent years. ${ }^{5}$ Taking into account post-tax Gini indices, there is a similar evolution of both groups of countries. More importantly, the figure shows that PR systems generally redistributed more, that is, the difference

\footnotetext{
4 To alleviate the reverse causality issue in the empirical analysis below, I focus exclusively on the effect of electoral systems in pre-tax income inequality.

5 One may be concerned about the presence of PR systems in non-democracies and non-PR systems in democracies. It should be noted that the sample shows a balance distribution of electoral systems by political regime types, by which one third of non-democracies use proportional rules, and around half of the sample democracies use proportional rules.
} 
PR Countries

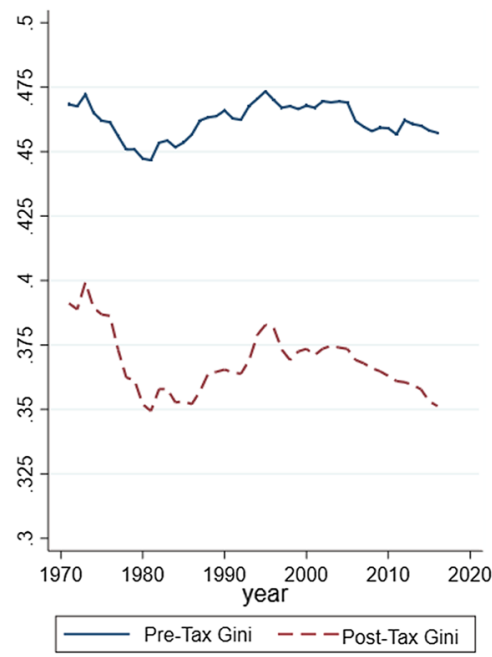

Non-PR Countries

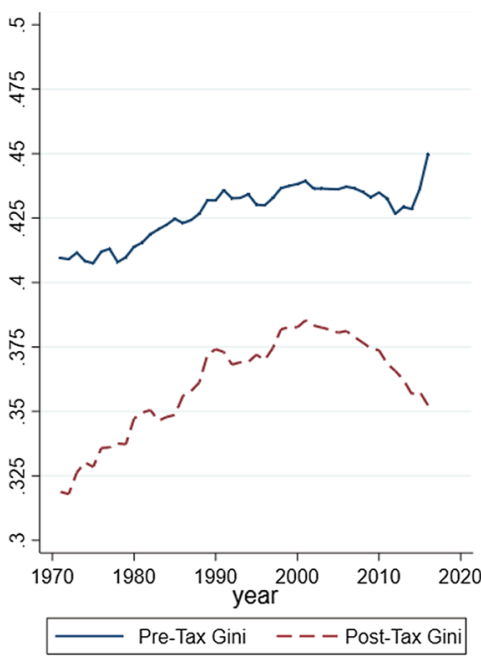

Fig. 3 Evolution of pre-tax and post-tax gini indices in PR and non-PR countries

between pre-tax and post-tax Gini indices is on average greater in PR systems than in non-proportional systems.

Existing works on the precise link of electoral systems in income inequality are scarce, and are summarised here. Theoretically, Austen-Smith (2000) observes that PR systems, usually characterised by more than two parties, exhibit higher tax rates and flatter income distribution than the typical two-party majoritarian electoral systems. Empirical research on these mechanisms tends to associate more proportional electoral systems with lower levels of within-country income inequality. Verardi (2005) focuses on the effect of district magnitude in electoral systems on income inequality. Using data on 28 countries and a 4-year time span, he finds that when the degree of proportionality increases, income inequality decreases. Along similar lines, Birchfield and Crepaz (1998) consider the larger number of effective parties under PR than in majoritarian systems to study the link between electoral systems and income inequality. Using data on 18 countries at two points in time, they find that PR systems (majoritarian systems) are associated with lower (higher) income inequality. Nevertheless, the literature calls for the use of more extensive databases as well as more computational demanding techniques and specifications, to provide sound empirical leverage to the link between electoral systems and income inequality.

\subsection{De jure and de facto political institutions}

Previous literature distinguishes the economic aftermath of de jure and de facto institutions, and shows the complementarity of both types of institutions to set the rules and enforcing the mechanisms to create economic prosperity. Empirical evidence shows that yet de jure and de facto judiciary institutions are correlated with economic growth, it seems that the latter play a more relevant role in enhancing development (Voigt et al. 
2015; Marciano et al. 2019). Directly related to the current paper, Spruk (2016) constructs latent de jure and de facto measures of political institutions to find a persistent impact of the latter in long-run development. Further, Hartmann and Spruk (2020) provide evidence on that both de jure and de facto institutional instability are important deterrents of income and growth. This body of literature confirms the primacy of de facto over de jure political institutions in driving economic development. The present paper adds to this literature by focusing at the effect of de jure and de facto political institutions in income inequality.

The second hypothesis of this paper is that the effect of electoral systems in income inequality hinges on political equality. Hence, I consider the interplay between de jure and de facto political institutions to impact on income inequality. Theoretically, I draw on the model in Acemoglu and Robinson (2008) that shows how changes in de jure political institutions might be offset by de facto political institutions, thus perpetuating equilibrium outcomes. I applied the model provided by Acemoglu and Robinson (2008) to the case of changes in electoral systems that distribute more de jure political power to the masses (e.g. more proportional systems). The final economic outcome of those changes, authors suggest, might depend on the de facto power of a political elite to distort the political process in their favour. As a result, inequalityreducing de jure political changes may be countervailed by low levels of political equality, thus perpetuating income inequality.

Changes in electoral systems, as de jure institutional changes, and their interplay with political equality, as a de facto political institution, are indeed a perfect platform to test the theoretical model in Acemoglu and Robinson (2008). The next section empirically tests whether changes in de jure political institutions and their interplay with de facto institutions affects income inequality. Nonetheless, it should be noted that previous research has also focused on the reverse mechanism, i.e. income inequality as a causal determinant of political equality (Solt 2008; Houle 2018).

Notwithstanding the econometric techniques employed here to circumvent reverse causality issues, the reader should feel free to interpret the results as partial correlations. Recalling the critique in Krauss (2016) on the limits of inferring causal mechanisms in macro-level frameworks, the modest goal of the current paper is to look at the role of political institutions in income inequality in a manner that existing literature has not yet explored in detail. In any case, the empirical approach taken in the current paper supplements previous research on the electoral systems-income inequality link (Birchfield and Crepaz 1998; Verardi 2005) in its specific aspect, and aims to contribute to the debate on democracy-income inequality in general by considering more nuanced conceptualisations of political institutions.

\section{Empirical analysis}

This paper tests whether electoral systems are related with within-country income inequality, and whether this relationship hinges upon the distribution of political power across socio-economic groups of the population. This section describes the data employed, the econometric specifications and the main results. I link data on income inequality with information on electoral systems and political equality, along 
with other empirically informed factors of inequality, and construct an unbalanced database on 85 countries using annual data for 1960-2016. The preferred model uses 2567 country-year observations, although this number varies upon data availability in alternative models. Let's consider the dynamic panel data model in Eq. 1.

$$
\begin{aligned}
Y_{c t} & =\beta_{0}+\rho Y_{c, t-s}+\beta_{1} \mathrm{PR}_{c, t-s}+\beta_{2} \mathrm{PE}_{c, t-s}+\beta_{3} \mathrm{PR} * \mathrm{PE}_{c, t-s}+X_{c, t-s}^{\prime} \beta+u_{c t} \\
u_{c t} & =\delta_{c}+\gamma_{t}+\epsilon_{c t} \\
c & =\text { country; } t=\text { year; } s=\{1,5,10\}
\end{aligned}
$$

\subsection{Dependent variable: pre-tax Gini index}

Where $Y_{c t}$ is the pre-tax Gini coefficient based on households' income, taken from the Standardized World Income Inequality Database (SWIID) (version 8.1, May 2019) (Solt 2019), ranging between 0 (perfect equality) and 1 (perfect inequality). The SWIID is an imputation-based dataset produced privately by individual researchers, and it is calculated using a multiple-imputation method based on primary and secondary data sources. The SWIID provides comprehensive data on pre-tax (market Gini index) and post-tax (net Gini index) income inequality, as well as relative and absolute rates of redistribution, and allows comparison across countries (De Haan and Sturm 2017). The SWIID data comes at the cost of potential bias and precision issues (Jenkins 2015; Ferreira et al. 2015). Additionally, as stated in Houle (2017), SWIID data is likely to suffer from measurement errors specifically in the case of developing countries. Nevertheless, previous work suggest that the SWIID data is still worthy-using so long as its larger coverage of countries and time periods enable the use of proper estimation strategies (Solt 2015; Houle 2017).

The choice of the pre-tax instead of the post-tax Gini index as the main dependent variable in this paper is made based on the pre-post approach debate (Bergh 2005; De Haan and Sturm 2017). Recall that the focus of this paper is on income inequality rather than redistribution. Using the post-tax Gini index as the main dependent variable would be misleading and might impose further endogeneity issues, as the consequences of redistribution and pro-poor policy demands of the electorate on the choice of electoral system might exacerbate reverse causation. By placing greater attention on pre-tax income inequality, the role of government and redistribution in income inequality is alleviated to a certain extent, and thus the endogeneity issue.

\subsection{Independent variables: electoral systems and political equality}

\subsubsection{Focal independent variables}

The dynamic model in Eq. 1 includes first preliminary realisations of income inequality $\left(\rho Y_{c, t-s}\right)$. The focal right-hand-side variables in the model are first, a dummy variable that takes the value of one for proportional systems (PR hereafter) for each country and year $\left(\mathrm{PR}_{c, t-s}\right)$, collected from the Democratic Electoral Systems (DES) Dataset by 
Bormann and Golder (2013) (version 3.0), and second, the level of political equality $\left(\mathrm{PE}_{c, t-s}\right)$, collected from the Varieties of Democracy (V-Dem) Database (version 9, April 2019). Remember that $s$ in Eq. 1 stands for a one period lag, which could be a 1-year $(s=1)$, 5-year $(s=5)$ or 10-year $(s=10)$ non-overlapping time period. The use of the non-contemporary effects of electoral systems and political equality on income inequality, along with the use of longer periods might alleviate endogeneity issues in the estimation.

Electoral systems are usually divided into three main categories: majoritarian rule, PR systems and mixed systems. This paper groups together majoritarian and mixed systems (non-PR hereafter) to emphasise the role of more proportionality in parliaments in income inequality. ${ }^{6}$

The database used for the following econometric models contains 24 changes in electoral systems, either from or to PR and non-PR systems, which took place in 21 countries, as shown in Table 3 in the Appendix. It should be noted that electoral system changes rarely occur, thus reducing the across and within-country variability in the data. ${ }^{7}$ Nevertheless, as Acemoglu et al. (2015) suggest with respect to political regime changes, countries that never change electoral system may still provide us with information about changes in income inequality as a function of previous levels of political equality and income inequality.

The V-Dem measure of political equality ${ }^{8}$ is defined as the extent to which political power is evenly distributed according to socio-economic groups of individuals (Pemstein et al. 2015). The conceptualisation of political equality is built on the real political power that a group of individuals wield based on whether they (a) actively participate in politics (by voting, etc. et al.); (b) are involved in civil society organisations; (c) secure representation in government; (d) are able to set the political agenda; e) influence political decisions; and (f) influence the implementation of those decisions. I normalised this variable in a continuous range between 0 and 1 to ease the interpretation of the estimates.

\subsubsection{Control variables}

Following standard literature, the term $X_{c, t-1}$ in Eq. 1 includes a set of controls, which include economic growth, globalisation, education and other empirically informed drivers of inequality. The summary of statistics and the set of controls are respec-

\footnotetext{
${ }^{6}$ I used dummies for majoritarian systems in alternative models, which are available upon request, and achieved similar results.

${ }^{7}$ As noted by an anonymous reviewer, is important to consider the stability of the share of PR countries in the sample (Mukand and Rodrik 2020). Giving the unbalanced nature of the panel database employed in this paper, the share of PR countries remains relatively constant along the time dimension considered. See Figure $\mathrm{S} 1$ in the online supplementary material.

8 Table 4 in the Appendix provides cross-correlations of the various political institutions considered in the analysis, and shows a correlation lower than 0.5 between various measures of democracy and political equality. Democracy, and its measurement, is mainly focused on de jure features of the political process, such as the extension of franchised population or alternation of parties in power under identical rules. Hence, these measures might fail to indicate the level of de facto political power distributed within the electorate from different socio-economic status, and indeed are conceptually different from what we understand as political equality.
} 
tively in Tables 5 and 6 in the Appendix. Economic development is proxied using the gross domestic product per capita data collected by the World Bank (constant 2011 international \$). The so-called inverted U-shaped relationship between economic development and inequality formalised by Kuznets (1955) states that income inequality first increases in the course of economic development, then peaks, and finally decreases at high levels of economic development. However, there is growing evidence to support a U-shaped relationship, rather than an inverted U-shaped link, between economic development and inequality (Dreher and Gaston 2008), suggesting that inequality is high for low levels of development, decreases in the course of economic development and increases again in affluent countries. Indeed, Lessmann and Seidel (2017) explore the non-linearity of the GDP-inequality linkage in the context of regional inequality and find a cubic function by which GDP might have an N-shaped effect on inequality. The set of regressions below include the logarithm of GDP per capita, and its squared and cubic roots to test such non-linearity.

The term $X_{c, t-1}$ also includes the educational level of the population, which is related to reducing inequality (Gregorio and Lee 2002), the inequality-enhancing effect of the ratio of elderly people (Deaton and Paxson, 1998), urbanisation, globalisation and financial development trends (Dreher and Gaston 2008; Asteriou et al. 2014). ${ }^{9}$ To account for these latter factors, the preferred model in Eq. 1 includes the KOF Globalisation Index (Gygli et al. 2018) and foreign direct investment (FDI, World Data Bank), measured by net inflows from foreign investors as a percentage of GDP. ${ }^{10}$ Alternative models, which are available upon request, also considered the weight of agriculture and non-agriculture employment or value added as a percentage of GDP, with similar results to those provided here. However, the inclusion of these covariates come at the cost of reducing the number of electoral system change events in the dataset, and hence are excluded from the main analysis.

$X_{c, t-1}$ crucially controls for the varying degree of democracy. Neither maximal conceptualisations of democracy, such as Polity 2 provided by the Polity IV Project (Column 1 and 5, Table 6 in Appendix), nor minimal conceptualisations of democracy [Boix et al. (2013) Database (version 3.0)] (Column 6, Table 6 in Appendix) are associated with a significant role in income inequality. Nonetheless, the duration of democracy seems to play a minor role in inequality, which is measured in terms of the Boix-Miller-Rosato dichotomous concept of democracy.

Lastly, the terms $\delta_{c}$ and $\gamma_{t}$ refer to country fixed-effects that are removed in the estimation, and year fixed-effects, respectively, while $\epsilon_{c t}$ stands for the error term. All of the models include clustered standard errors at a country level to accurately account for heteroskedasticity and autocorrelation. Overall, this specification aims to supplement previous research on the link between electoral systems and income

\footnotetext{
9 The information source for these controls is the World Bank databases.

10 Alternative measures of financial institutions do not significantly alter the estimates provided here. For instance, alternative models include the Fraser Institute measure of economic freedom (Economic Freedom of the World), as it is done in Bergh and Nilsson (2010) and De Haan and Sturm (2017). These models yield similar results while the regressor associated with economic freedom is not associated with a significant role in the pre-tax Gini index. However, the country coverage and explanatory power of the models reduce when including this index.
} 
inequality by controlling for country fixed-effects, since their omission might give false results due to omitted variable bias (Acemoglu et al. 2015).

Endogeneity issues should be emphasised one more time before moving on to the findings. Notwithstanding the fact that the estimates below have a tentative causal interpretation under the usual assumptions of fixed-effects panel data models, I cannot deny the possibility of omitted factors driving both political and economic inequality. Likewise, a reverse causation from income inequality to political equality and electoral systems cannot be ruled out (Acemoglu et al. 2015; Scheve and Stasavage 2017). To alleviate this concern, all the independent variables are lagged one period.

\subsection{Preliminary results: static panel data models}

Within-group estimates of a static version of Eq. 1 generally associate PR with a negative impact on income inequality at a $10 \%$ level when the full set of controls is included (full estimates are shown in Table 6 in the Appendix). Higher levels of political equality are associated with lower pre-tax Gini coefficients, again at a $10 \%$ significance level, whereas the interaction between these variables is positive and significant (at a 10\% level). Importantly, the measure of democracy is not associated with an explanatory power over income inequality, and thus it might suggest that political equality is a stronger predictor of inequality than democracy.

These preliminary estimates support the N-shape effect of economic development on income inequality in Lessmann and Seidel (2017), as GDP per capita (GDP pc) enters the equation with a positive sign (initial levels of economic development), while the squared GDP pc is associated with a negative sign (medium levels of economic development), and further increases in GDP pc increase income inequality further (GDP pc cubed).

The preferred model in static estimates includes the age of the democracy, instead of measures of democracy, together with the full range of controls. To check the sensitivity of the estimates of this model, I consider th use of non-overlapping periods and the inclusion of lags of income inequality in the following section. An alternative model included in the static specifications (Column 8 in 6, Appendix) accounts for the potential effects of union density on income inequality. Union density and income inequality are found to be mutually related by Chauvel and Schröder (2017). Echoing this finding, I used the Data Base on Institutional Characteristics of Trade Unions, Wage Setting, State Intervention and Social Pacts (ICTWSS) for the period from 1960 to 2016. The main results provided here, which associate electoral systems and their interplay with political equality and income inequality, remain the same when controlling for union density. However, using data on unions halves the number of observations and the number of countries in the sample (1127 observations from 42 countries), and thus reducing the number of electoral system change events in the dataset. 


\subsection{Main results: dynamic panel data models}

We next consider static models with longer periods of time (5-year or 10-year nonoverlapping periods) and dynamic models estimated with within-group or Generalized Method of Moments (GMM) estimators. Both controlling for fixed effects and tackling the important dynamics in the key outcome variables will help to establish robust patterns between electoral systems and income inequality.

Equation 1 posits at least two major sources of endogeneity: country fixed-effects and the inclusion of the dependent variable. OLS cannot be used accurately in this model due to the presence of fixed-effects and correlation with the lagged dependent variable, and fixed-effects estimates incurring the so-called Nickell bias, since the regressor and error are still correlated after first-differentiating. Additionally, panel data settings might suffer from sorts of cross-country and temporal dependencies, and ignoring them can lead to biased statistical inference (Hoechle 2007). To solve for spatial correlation between countries in the sample, I use the nonparametric covariance matrix estimator developed by Driscoll and Kraay (1998) which produces heteroscedasticity consistent standard errors that are robust to very general forms of spatial and temporal dependence to estimate fixed-effects within regressions. ${ }^{11}$

The preferred model for estimating Eq. 1 is the system-GMM as developed in Arellano and Bover (1995) and Blundell and Bond (1998). The system-GMM removes country fixed-effects by firstly differentiating Eq. 1 , and instruments $Y_{c, t-s}$ with variables uncorrelated with the fixed effects, and includes standard errors that are clustered at country and time levels. It should be noted that the database employed is an unbalanced panel. Hence, first-differencing transformations might magnify the gaps in the data (Roodman 2009). To check the validity of the results below, I also conducted the forward orthogonal deviations transformation, which yielded the same main results. I restricted the number of lags and collapsed the instruments so as to limit its proliferation, as proposed in Roodman (2009). Both within-group and system-GMM estimates are shown in Table 1 to check the consistency of the results. ${ }^{12}$

Table 1 shows the main findings of the paper. PR and political equality are generally associated with a reducing effect in income inequality. Additionally, the results prove that the inclusion of previous realisations of income inequality in the regression model is mandatory to avoid omitted variable bias. Column 1 shows within-group estimates using annual data, ${ }^{13}$ whereas Columns $2-3$ use non-overlapping 5-year and 10-year periods respectively from 1960 to 2016, without including lags of the pre-tax Gini index in the right-hand-side variables. The interaction between PR and political equality is positively associated with income inequality and is statistically significant in the

\footnotetext{
11 The Driscoll and Kraay (1998) estimates are a superior technique relative to the commonly used heteroscedasticity and autocorrelation consistent standard errors estimates in the reference literature. As postestimation analysis for the fixed-effects within regressions, I perform the adapted Hausman test which is robust to very general forms of spatial and temporal dependence (Hoechle 2007; Wooldridge 2010), which are available upon request.

12 As an alternative sensitivity analysis of the main results, I conducted an additional instrumental variable model to check the symmetry of the results. This model uses a dummy for changes in electoral systems, either MR, MS or PR systems, instead of a dummy for PR countries. The estimates are plotted in Figure S2 and confirms the symmetry of the main findings.

13 This model is the same model in Column 7 Table 6 in the Appendix.
} 


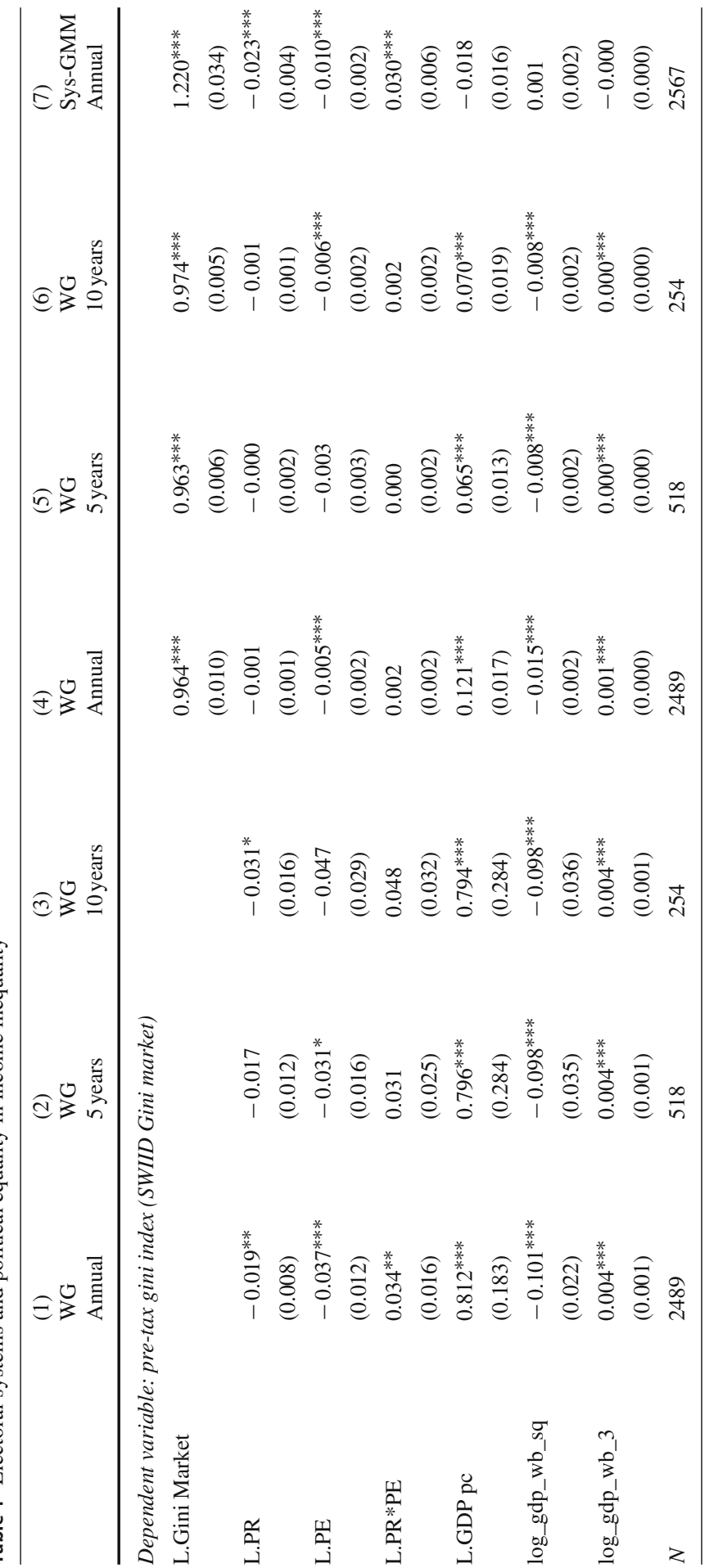




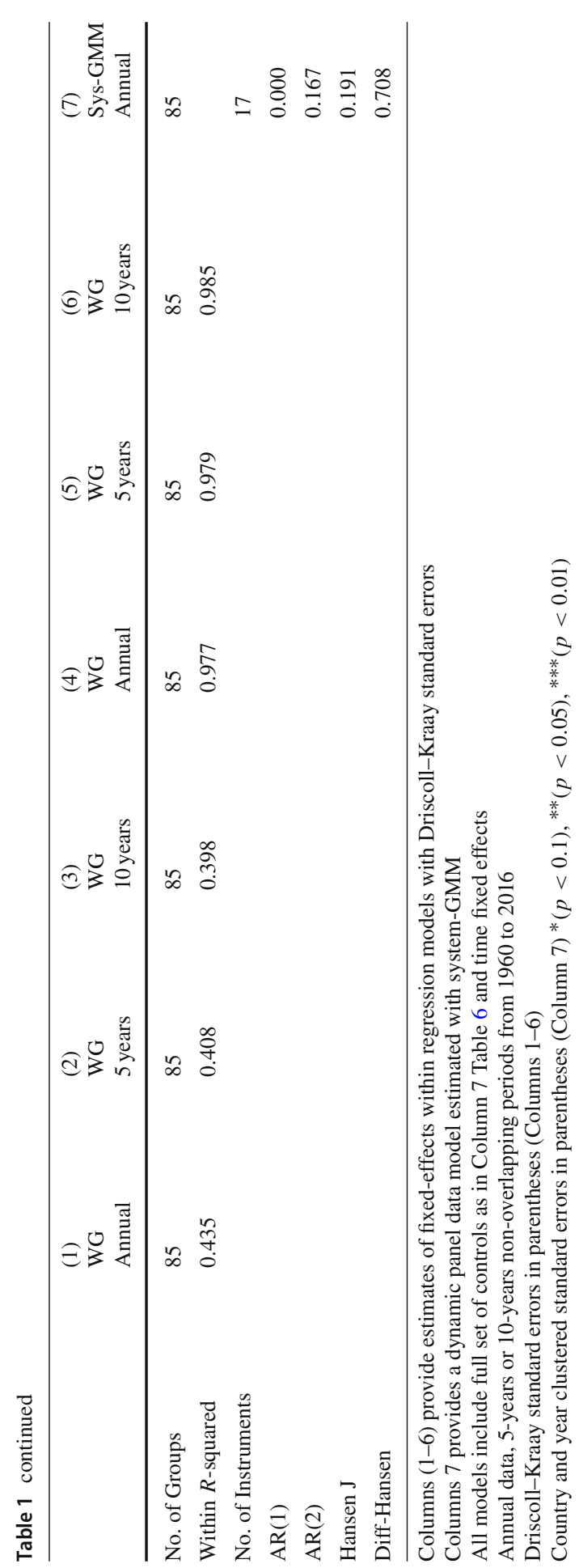




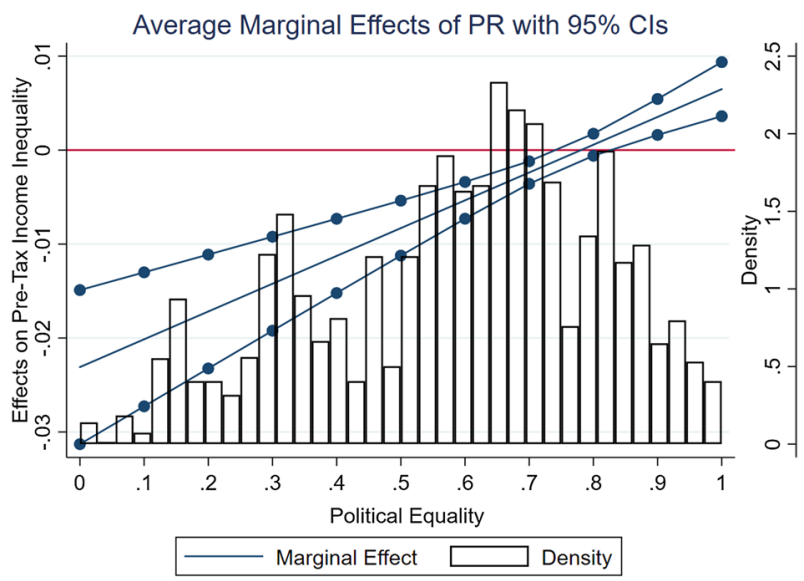

Fig. 4 Effect of PR by political equality (system-GMM estimates)

models that use annual data (Columns 1 and 7, Table 1). As a further robustness check, I conducted population-weighted additional models which show similar results to the main findings (see Table S1 in the online supplementary material).

Columns 4-7 (Table 1) include lags of the dependent variable, and use either annual (1960-2016), 5-year or 10-year non-overlapping periods (1960-2016). The lagged pre-tax Gini index is associated with an increasing effect in current income inequality. The presence of the lagged dependent variable biases within-group estimates. Thus, I apply the system-GMM to the model in Eq. 1 in Column 7 (Table 1). Instrumental variables results provide further leverage of the inequality effect of electoral systems: PR is associated with a negative and significant role in income inequality, political equality is also negatively associated with inequality, and the interaction is positive and statistically significant.

Figure 4 represents the average marginal effect estimated in Column 7 (Table 1) on the pre-tax Gini index for changes in electoral systems to PR in $t-1$ by different levels of political equality, while showing a histogram of the distribution of real political power in the sample. ${ }^{14}$ The interactive model specified in Eq. 1 assumes that the effect of PR varies at different levels of political equality and, thus, the final effect might consider the interaction, provided it is significant, times the level of political equality. ${ }^{15}$ PR is associated with reducing income inequality at low and medium levels of political equality. As societies become more politically equal, the inequality-reducing effect of changes in electoral system reduces in magnitude.

Table 2 provides a closer look at the marginal effects of electoral systems on income inequality at different levels of political equality. Considering the average marginal effects of lagged PR on income inequality with clustered standard errors at country and time levels, we find that, beyond a level of 0.8 for political equality, changes in electoral systems are associated with increasing income inequality. The point estimates imply

14 Using 5-year and 10-year non-overlapping periods, system-GMM estimator yields similar results.

15 That is, the partial derivative of Eq. 1 with respect to $\mathrm{PR}_{c, t-1} ; \frac{\delta\left(Y_{c t}\right)}{\delta\left(\mathrm{PR}_{c, t-1}\right)}=\beta_{1}+\beta_{3} * \mathrm{PE} c, t-1$. 
Table 2 Average marginal effects of PR on pre-tax gini index at different levels of political equality

\begin{tabular}{lrlcc}
\hline Political equality & $\mathrm{d} y / \mathrm{d} x$ & Clustered S.E. & $z$ & $p$ value \\
\hline 0 & -0.023 & 0.004 & -5.52 & 0.000 \\
0.25 & -0.016 & 0.003 & -5.56 & 0.000 \\
0.50 & -0.008 & 0.005 & -5.57 & 0.000 \\
0.75 & -0.001 & 0.001 & -1.69 & 0.091 \\
1 & 0.006 & 0.001 & 4.42 & 0.000 \\
\hline
\end{tabular}

Marginal estimates of system-GMM model (Column 7, Table 1)

that, when there is a monopoly of political power $(\mathrm{PE}=0)$, a change to PR in the previous period decreases income inequality in the current period by about 0.02 point of the pre-tax Gini coefficient (at a significance level of 1\%). For values of political equality around 0.25 and $0.5(\mathrm{PE}=0.5)$, the same change in electoral system will reduce the pre-tax Gini index by 0.16 and 0.01 points (at a significance level of $1 \%$ ). For countries with a level of political equality of over 0.75 , changes in the electoral system are associated with a reducing effect in the pre-tax Gini index of 0.001 at $10 \%$ of significance, whereas for highly political equal countries $(\mathrm{PE}=1)$, changes to PR systems increases pre-tax income inequality by 0.01 points of Gini coefficient.

The estimates indicate that in political unequal societies, such as the case of Ukraine (2000-2003), Argentina (1977-1982), Chile (1977-1987) and the Philippines (1971), changes to PR seem to reduce income inequality. However, the results tend to suggest that in more politically equal societies, such as Madagascar (1999-2006) or Romania (2007-2013), changes to PR are also associated with a reducing effect on income inequality, although to a lesser extent. Lastly, in societies with even distributions of real political power (New Zealand, Finland, Sweden, among others), the role of electoral systems in income inequality does not seem significant.

One mechanism behind the above results might be that voters are divided beyond economic inequality (Roemer 2009; Scheve and Stasavage 2017), and this argument may play a stronger role for those societies with even distributions of real political power. The estimates suggest that when more political representation is granted to minority groups in unequal societies, there is a mechanism by which income inequality can be reduced. However, this does not seem to apply when there is a greater de jure representation of minorities in politically equal societies. A potential explanation for the different ways that electoral changes affect income inequality, depending on the distribution of political power, might reflect different political demands of minority groups in low, median and highly political equal societies. A further consideration of this explanation requires knowing the kind of political demands of newly represented groups in parliaments and their preferences over inequality-correcting policies, an exercise that I leave for future research.

Other potential mechanisms at work in the inequality-increasing effect of more proportionality in political equal societies go along new evidence on the link between democratic rule and income inequality. Recent contributions to the literature suggest that higher inclusiveness in the political process, while keeping contestation equal (Wong 2021), and high state capacity (Bahamonde and Trasberg 2021), can increase 
within-country income inequality through repetitively, political capture by elites and alienation of marginalized groups, and financial development.

Consistent with previous literature de jure and de facto political institutions (Voigt et al. 2015; Spruk 2016; Hartmann and Spruk 2020), the estimates imply differentiated economic effects of both types of institutions. More precisely, the estimates speak to the increasing political stability of more proportional systems (Cox and McCubbins 1994) and de jure and de facto political institutions (Hartmann and Spruk 2020), such as electoral systems and political equality, in producing varying levels of within-country income inequality. Finally, similarly to Spruk (2016), I find different absolute magnitudes of the economic effects of de jure and de facto political institutions. However, based on the instrumentalist variable estimates, the role of electoral systems (as de jure political institution) is greater than that of political equality (as de facto political institution) in within-country income inequality. ${ }^{16}$

\section{Conclusion}

The starting point for this paper was the observation of rising within-country income inequality in established democracies. In theory, democratic governments should be able to correct for rising inequality through the processes of enfranchisement and political competition. In practice, democratic governments have coexisted and been callously indifferent about rising levels of income inequality over the last few decades. This paper aims to advance our understanding of the link between democracy and inequality by approaching the issue from an alternative perspective. Using a conceptualisation of democratic political institutions that differentiates between de jure and de facto political institutions, I argue that de jure politico-institutional changes that might, in principle, lower inequality can be countervailed by de facto political power. Specifically, the paper surmises two hypotheses. Firstly, electoral systems, which are used to translate votes into seats on a different basis, have an effect on income inequality. Secondly, I argue that this effect is contingent upon political equality in the country.

I construct an extensive database, linking data on income inequality and political institutions, that supplements previous research in terms of time and country coverage, with the inclusion of empirically informed drivers of inequality. I specify static and dynamic panel data models, use alternative estimation techniques, and use either annual data or 5-year and 10-year non-overlapping periods. The results significantly associate proportional representation systems with lower income inequality. The results also find that the impact of electoral systems on inequality is contingent on the distribution of political power in society. More precisely, instrumental variable estimates show that at low and median levels of political equality, changes towards proportional representation systems reduce income inequality, and the magnitude of the effect reduces as societies become more politically equal. Strikingly, in highly political equal societies, changes towards more proportional electoral systems are associated with rising income inequality. The estimates include a variety of controls, in which importantly, none of the alternative measures of democracy is significantly

$\overline{16}$ The coefficients associated with PR and PE are respectively -0.023 and -0.01 (Column 7, Table 1). 
associated with income inequality. The estimates robustly support the N-shape relationship between economic development and income inequality found in Lessmann and Seidel (2017).

These findings add new evidence on the workings of the political institutional settings in producing within-country income distribution. The paper shows that increasing proportionality in politically unequal societies is associated with lower pre-tax Gini coefficients, whereas the same changes in politically equal societies seem to be unrelated to income inequality. The interpretation of these results might follow along the lines of Roemer (2009), who argued that voters' preferences might be unrelated to or go beyond economic inequality issues. The results here suggest that this reasoning might specifically apply to politically equal societies.

Additionally, the above estimates breathe new life in our understanding of the economic effects of de jure and de facto political institutions. Along the lines of Spruk (2016) and Hartmann and Spruk (2020), the current paper finds that both electoral systems (de jure) and political equality (de facto) play different roles in the economy, and that both should be accounted for in regression models.

All in all, the findings of this paper might help to identify in which type of societies changes in electoral systems might lead to reducing income inequality. At the same time, the paper shows how more nuanced conceptualisations of political institutions, such as the de jure versus de facto characterisations, might allow a better understanding of the political causes of income distribution. Nonetheless, there are several questions still to be answered related to the mechanisms behind the above findings. Two natural extensions of the current paper emerge. Exploring how the political stability of both de jure and de facto political institutions intertwine with income distribution would provide a better knowledge of the political-institutional underpinning of income inequality. Additionally, future research on the interplay between electoral systems, political equality and inequality should consider micro-level approaches with information on the political demands of minority and newly enfranchised groups.

Supplementary Information The online version contains supplementary material available at https://doi. org/10.1007/s00181-021-02154-9.

Acknowledgements Earlier versions of this paper were presented at the 1st Conference of the Catalan Economic Society (CES), Barcelona, Spain (2017), 21st Annual Conference of the Society for Institutional \& Organizational Economics (SIOE), Columbia University, New-York, USA (2017), and 31st Annual Meeting European Association for Evolutionary Political Economy (EAEPE), Warsaw School of Economics, Poland (2019). I would like to thank Adam Przeworski, Steven Stillman and Jakob Kapeller for helpful comments. The research received funding from the Spanish State Research Agency and the European Regional Development Fund ECO2016-76884-P, and by the Ph.D. scholarship of the Spanish Ministry of Economy and Competitiveness (MINECO).

Funding Open Access funding enabled and organized by Projekt DEAL.

\section{Declarations}

Conflict of interest There is no conflict of interest in this research. 
Ethical approval This article does not contain any studies with human participants performed by any of the authors.

Open Access This article is licensed under a Creative Commons Attribution 4.0 International License, which permits use, sharing, adaptation, distribution and reproduction in any medium or format, as long as you give appropriate credit to the original author(s) and the source, provide a link to the Creative Commons licence, and indicate if changes were made. The images or other third party material in this article are included in the article's Creative Commons licence, unless indicated otherwise in a credit line to the material. If material is not included in the article's Creative Commons licence and your intended use is not permitted by statutory regulation or exceeds the permitted use, you will need to obtain permission directly from the copyright holder. To view a copy of this licence, visit http://creativecommons.org/licenses/by/4.0/.

\section{Appendix}

Dataset for replication and codes are available from the author upon request at izzuazu(at)gmail.com or izaskun.zuazu-bermejo@uni-due.de

List of countries: Argentina, Armenia, Australia, Austria, Bangladesh, Barbados, Belgium, Benin, Bolivia, Brazil, Bulgaria, Burundi, Canada, Chile, Colombia, Costa Rica, Czech Republic, Denmark, Dominican Republic, Ecuador, El Salvador, Estonia, Fiji, Finland, France, Georgia, Germany, Ghana, Greece, Guatemala, Honduras, Hungary, Iceland, India, Ireland, Israel, Italy, Jamaica, Japan, Kenya, Korea, Kyrgyzstan, Latvia, Lebanon, Liberia, Lithuania, Madagascar, Malawi, Mali, Mauritania, Mauritius, Mexico, Moldova, Myanmar, Nepal, Netherlands, New Zealand, Nicaragua, Niger, Nigeria, Norway, Pakistan, Panama, Paraguay, Peru, Philippines, Poland, Portugal, Romania, Senegal, Sierra Leone, Slovakia, Spain, Sri Lanka, Sweden, Switzerland, Thailand, Trinidad and Tobago, Turkey, Uganda, Ukraine, United Kingdom, United States, Uruguay, Venezuela 
Table 3 Changes in electoral system in database

\begin{tabular}{lllllllr}
\hline Country & From & To & Year & Country & From & To & Year \\
\hline Argentina & MR & PR & 1963 & Madagascar & PR & MS & 1998 \\
France & MR & PR & 1986 & Philippines & MR & MS & 1998 \\
Turkey & PR & MS & 1987 & Ukraine & MR & MS & 1998 \\
France & PR & MR & 1988 & Thailand & MR & MS & 2001 \\
Korea & MR & MS & 1988 & Sierra Leone & PR & MR & 2002 \\
Panama & PR & MS & 1989 & Ecuador & MS & PR & 2002 \\
Sri Lanka & MR & PR & 1989 & Italy & MS & PR & 2006 \\
Venezuela & PR & MS & 1993 & Ukraine & MS & PR & 2006 \\
Paraguay & MS & PR & 1993 & Greece & PR & MS & 2007 \\
Italy & PR & MS & 1994 & Madagascar & MS & MR & 2007 \\
Turkey & MS & PR & 1995 & Romania & PR & MS & 2008 \\
Sierra Leone & MR & PR & 1996 & Bulgaria & PR & MS & 2009 \\
Japan & MR & MS & 1996 & Ukraine & PR & MS & 2012 \\
New Zealand & MR & MS & 1996 & Greece & MS & PR & 2012 \\
Bolivia & PR & MS & 1997 & Bulgaria & MS & PR & 2013 \\
Ecuador & PR & MS & 1998 & Romania & MS & PR & 2016 \\
\hline & & & & & & M
\end{tabular}

Table 4 Cross-correlation of political institutions

\begin{tabular}{lllcr}
\hline Variables & PR & Political equality & Democracy (Boix) & Polity 2 \\
\hline Political equality & 0.180 & & & \\
Democracy (Boix) & 0.192 & 0.439 & 0.861 & \\
Polity 2 & 0.181 & 0.495 & -0.167 & 0.030 \\
Age of democracy & 0.020 & 0.184 & \\
\hline
\end{tabular}


Table 5 Summary statistics

\begin{tabular}{lcccll}
\hline Variable & Obs & Mean & SD & Min & Max \\
\hline Pre-tax Gini Index & 2567 & 0.448 & .0057 & 0.215 & 0.604 \\
PR & 2567 & 0.534 & 0.499 & 0 & 1 \\
Political equality & 2567 & 0.639 & 0.208 & 0 & 1 \\
GDP pc (log) & 2566 & 8.911 & 1.492 & 5.391 & 11.425 \\
Elderly ratio & 2513 & 9.372 & 5.263 & 2.175 & 26.015 \\
Education & 2567 & 8.434 & 3.061 & 0.868 & 13.61 \\
Urbanization & 2567 & 62.044 & 21.142 & 7.01 & 97.92 \\
KOF & 2513 & 62.261 & 15.485 & 23.29 & 90.67 \\
FDI & 2499 & 3.153 & 5.59 & -28.62 & 87.44 \\
Polity2 & 2508 & 7.068 & 4.545 & -9 & 10 \\
Democracy & 2513 & 0.846 & 0.361 & 0 & 1 \\
Age of democracy & 2513 & 41.78 & 43.693 & 1 & 216 \\
Union density & 1033 & 33.696 & 21.542 & 4.4 & 98.7 \\
\hline
\end{tabular}

Based on column 7 (Table 1) 


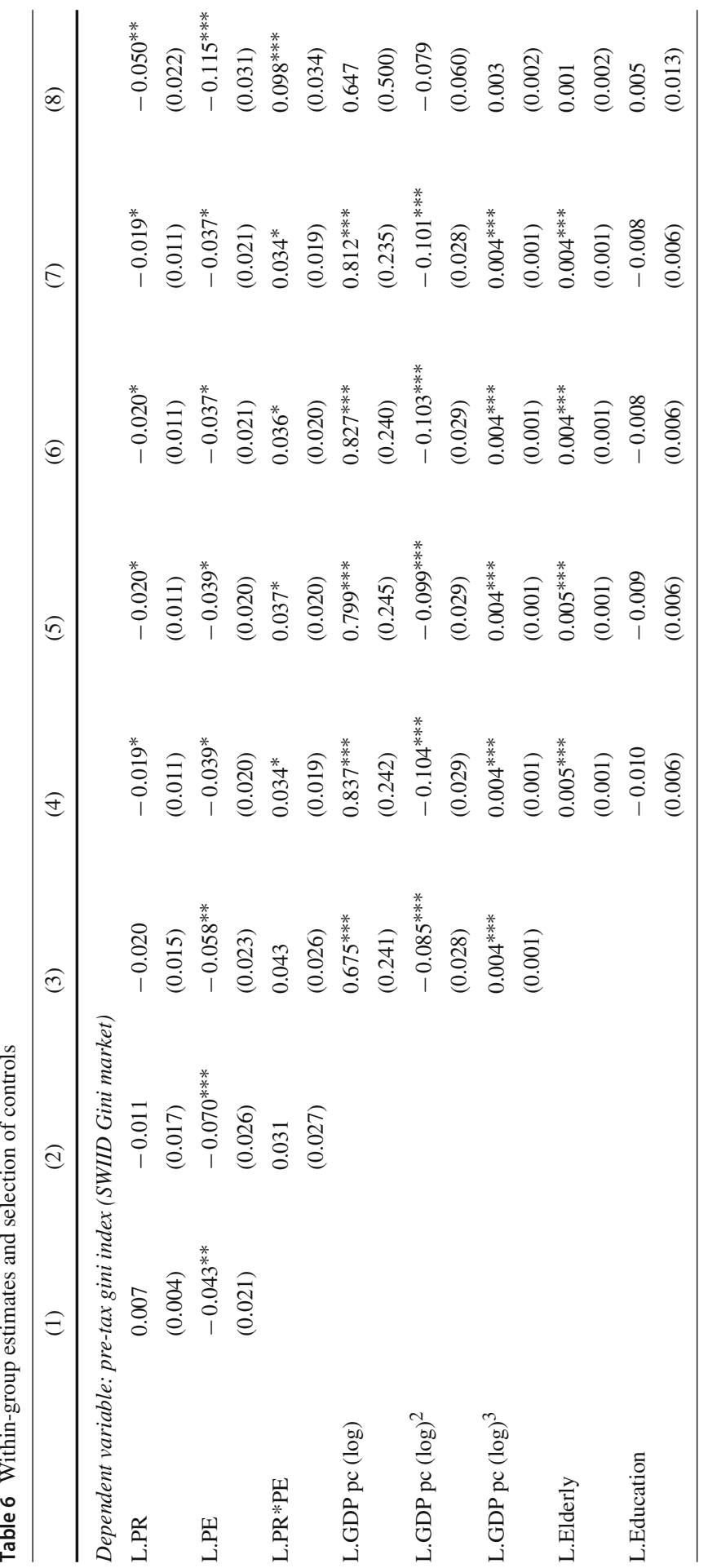




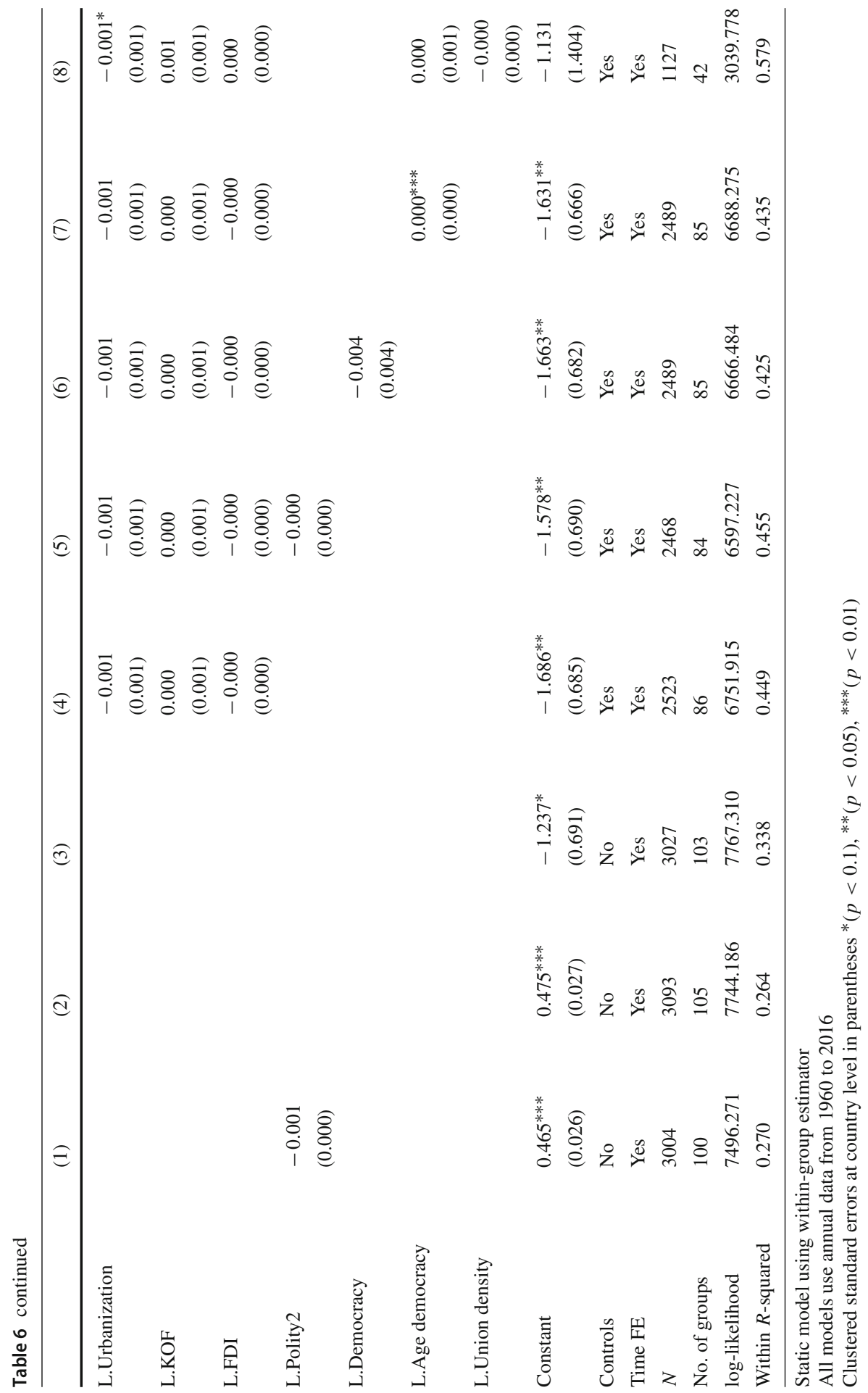




\section{References}

Acemoglu D, Robinson JA (2008) Persistence of power, elites, and institutions. Am Econ Rev 98(1):267

Acemoglu D, Naidu S, Restrepo P, Robinson JA (2013) Democracy, redistribution and inequality. Technical report, National Bureau of Economic Research

Acemoglu D, Naidu S, Restrepo P, Robinson JA (2015) Democracy, redistribution, and inequality. In: Atkinson AB, Bourguignon F (eds) Handbook of income distribution, vol 2. Elsevier, Amsterdam, pp 1885-1966

Aidt TS, Daunton M, Dutta J (2010) The retrenchment hypothesis and the extension of the franchise in England and Wales. Econ J 120(547):990-1020

Arellano M, Bover O (1995) Another look at the instrumental variable estimation of error-components models. J Econom 68(1):29-51

Asteriou D, Dimelis S, Moudatsou A (2014) Globalization and income inequality: a panel data econometric approach for the EU 27 countries. Econ Model 36:592-599

Atkinson AB (2015) Inequality. Harvard University Press, Cambridge

Austen-Smith D (2000) Redistributing income under proportional representation. J Polit Econ 108(6):12351269

Bahamonde H, Trasberg M (2021) Inclusive institutions, unequal outcomes: democracy, state capacity, and income inequality. Eur J Polit Econ. https://doi.org/10.1016/j.ejpoleco.2021.102048

Bartels LM (2017) Political inequality in affluent democracies: the social welfare deficit. In: 4th Conference in political economy and political science (assessing democratic institutions), Toulouse, March. pp $23-24$

Benabou R (2000) Unequal societies: income distribution and the social contract. Am Econ Rev 90:96-129

Bergh A (2005) On the counterfactual problem of welfare state research: How can we measure redistribution? Eur Sociol Rev 21(4):345-357

Bergh A, Nilsson T (2010) Do liberalization and globalization increase income inequality? Eur J Polit Econ 26(4):488-505

Berlinski S, Dewan T et al (2011) The political consequences of franchise extension: evidence from the second reform act. Q J Polit Sci 6(34):329-376

Besley T, Persson T, Sturm DM (2010) Political competition, policy and growth: theory and evidence from the us. Rev Econ Stud 77(4):1329-1352

Birchfield V, Crepaz MM (1998) The impact of constitutional structures and collective and competitive veto points on income inequality in industrialized democracies. Eur J Polit Res 34(2):175-200

Blundell R, Bond S (1998) Initial conditions and moment restrictions in dynamic panel data models. J Econom 87(1):115-143

Boix C (1999) Setting the rules of the game: the choice of electoral systems in advanced democracies. Am Polit Sci Rev 93(3):609-624

Boix C, Miller M, Rosato S (2013) A complete data set of political regimes, 1800-2007. Comp Polit Stud 46(12):1523-1554

Bormann N-C, Golder M (2013) Democratic electoral systems around the world, 1946-2011. Elect Stud 32(2):360-369

Chang EC, Higashijima M (2021) The choice of electoral systems in electoral autocracies. Gov Oppos. https://doi.org/10.1017/gov.2021.17

Chauvel L, Schröder M (2017) A prey-predator model of trade union density and inequality in 12 advanced capitalisms over long periods. Kyklos 70(1):3-26

Chong A, Gradstein M (2019) Institutional persistence, income inequality, and individual attitudes. J Econ Inequal 17:1-13

Cowell FA (2000) Measurement of inequality. In: Atkinson AB, Bourguignon F (eds) Handbook of income distribution, vol 1. Elsevier, Amsterdam, pp 87-166

Cox GW, McCubbins MD (1994) Bonding, structure, and the stability of political parties: party government in the house. Legis Stud Q 19:215-231

De Haan J, Sturm J-E (2017) Finance and income inequality: a review and new evidence. Eur J Polit Econ 50:171-195

Dreher A, Gaston N (2008) Has globalization increased inequality? Rev Int Econ 16(3):516-536

Driscoll JC, Kraay AC (1998) Consistent covariance matrix estimation with spatially dependent panel data. Rev Econ Stat 80(4):549-560 
Ferreira FH, Lustig N, Teles D (2015) Appraising cross-national income inequality databases: an introduction. J Econ Inequal 13(4):497-526

Franzini M, Pianta M (2015) Explaining inequality. Routledge, Milton Park

Gregorio JD, Lee J-W (2002) Education and income inequality: new evidence from cross-country data. Rev Income Wealth 48(3):395-416

Gygli S, Haelg F, Sturm J-E (2018) The kof globalisation index-revisited. KOF working papers, 439

Hartmann S, Spruk R (2020) Long-term effects of institutional instability. Empir Econ 61:1-40

Herron ES, Pekkanen RJ, Shugart MS (2018) The Oxford handbook of electoral systems. Oxford University Press, Oxford

Hoechle D (2007) Robust standard errors for panel regressions with cross-sectional dependence. Stat J $7(3): 281-312$

Houle C (2017) Inequality, ethnic diversity, and redistribution. J Econ Inequal 15(1):1-23

Houle C (2018) Does economic inequality breed political inequality? Democratization 25:1-19

Iversen T, Soskice D (2006) Electoral institutions and the politics of coalitions: why some democracies redistribute more than others. Am Polit Sci Rev 100(02):165-181

Jenkins SP (2015) World income inequality databases: an assessment of WIID and SWIID. J Econ Inequal 13(4):629-671

Kono DY (2009) Market structure, electoral institutions, and trade policy. Int Stud Q 53(4):885-906

Krauss A (2016) The scientific limits of understanding the (potential) relationship between complex social phenomena: the case of democracy and inequality. J Econ Methodol 23(1):97-109

Kuznets S (1955) Economic growth and income inequality. Am Econ Rev 45(1):1-28

Larcinese V (2011) Enfranchisement and representation: Italy 1909-1913

Lessmann C, Seidel A (2017) Regional inequality, convergence, and its determinants-a view from outer space. Eur Econ Rev 92:110-132

Lizzeri A, Persico N (2001) The provision of public goods under alternative electoral incentives. Am Econ Rev 91:225-239

Marciano A, Melcarne A, Ramello GB (2019) The economic importance of judicial institutions, their performance and the proper way to measure them. J Instit Econ 15(1):81-98

Marshall MG, Gurr TR, Jaggers K (2017) Polity iv project: political regime characteristics and transitions, 1800-2016. Center for Systemic Peace

Meltzer AH, Richard SF (1981) A rational theory of the size of government. J Polit Econ 89:914-927

Midtbø T (2018) Democracy and the demand for government redistribution: a survey analysis. Eur J Polit Res 57(4):829-844

Milanovic B (2000) The median-voter hypothesis, income inequality, and income redistribution: an empirical test with the required data. Eur J Polit Econ 16(3):367-410

Mukand SW, Rodrik D (2020) The political economy of liberal democracy. Econ J 130(627):765-792

Naoi M, Krauss E (2009) Who lobbies whom? Special interest politics under alternative electoral systems. Am J Polit Sci 53(4):874-892

Norris P et al (2004) Electoral engineering: voting rules and political behavior. Cambridge University Press, Cambridge

Pemstein D, Marquardt KL, Tzelgov E, Wang Y, Miri F (2015) The v-dem measurement model: latent variable analysis for cross-national and cross-temporal expert-coded data. V-Dem working Paper, 21

Persson T, Tabellini G (2004) Constitutions and economic policy. J Econ Perspect 18(1):75-98

Persson T, Roland G, Tabellini G et al (2007) Electoral rules and government spending in parliamentary democracies. Q J Polit Sci 2(2):155-188

Piketty T (2014) Capital in the twenty-first century. Harvard University Press, Cambridge

Rickard SJ (2012) Electoral systems, voters' interests and geographic dispersion. Br J Polit Sci 42(4):855877

Roemer JE (2009) Political competition: theory and applications. Harvard University Press, Cambridge

Roodman D (2009) How to do xtabond2: an introduction to difference and system GMM in stata. Stat J 9(1):86-136

Sala-i Martin X (2006) The world distribution of income: falling poverty and convergence, period. Q J Econ 121(2):351-397

Scheve K, Stasavage D (2009) Institutions, partisanship, and inequality in the long run. World Polit 61(02):215-253

Scheve K, Stasavage D (2017) Wealth inequality and democracy. Annu Rev Polit Sci 20:451-468

Solt F (2008) Economic inequality and democratic political engagement. Am J Polit Sci 52(1):48-60 
Solt F (2015) On the assessment and use of cross-national income inequality datasets. J Econ Inequal 13(4):683-691

Solt F (2019) Measuring income inequality across countries and over time: the standardized world income inequality database. SWIID Version, 8

Spruk R (2016) Institutional transformation and the origins of world income distribution. J Comp Econ 44(4):936-960

Verardi V (2005) Electoral systems and income inequality. Econ Lett 86(1):7-12

Verba S, Orren GR (1985) Equality in America: the view from the top. Harvard University Press, Cambridge

Voigt S (2013) How (not) to measure institutions. J Inst Econ 9(1):1-26

Voigt S, Gutmann J, Feld LP (2015) Economic growth and judicial independence, a dozen years on: crosscountry evidence using an updated set of indicators. Eur J Polit Econ 38:197-211

Wong MY (2021) Democracy, hybrid regimes, and inequality: the divergent effects of contestation and inclusiveness. World Dev 146:105606

Wooldridge JM (2010) Econometric analysis of cross section and panel data. MIT Press, Cambridge

Publisher's Note Springer Nature remains neutral with regard to jurisdictional claims in published maps and institutional affiliations. 